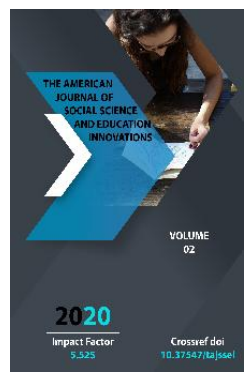

\title{
Common Use Semiotics On The Media Texts Which Express The Human Feelings
}

Journal Website: http://usajournalshub.c om/index,php/tajssei

\author{
Annaguliyev Jamshid \\ Masters Student, Foreign Philology Faculty Termez State University, Uzbekistan
}

\section{ABSTRACT}

The article mainly deals with the problems of the media text and its semiotic analysis due to the symbol embodying any idea; visible, audible rarer phenomenon, which people attach a special meaning that is not associated with the essence of this phenomenon. The research relevance is predetermined by the current evolutionary changes of media materials which connected with the latest developments in information and communication technologies. In the spanning globe, most social conversations are shortening with semiotic elements by communicating with as few letters as possible, and users created text message symbols as a sort of shorthand to make texting easier and faster. Most symbols make sense and have become a mainstay in texting language. Media symbols, not only save time, but be able to send longer texts that contain more personality and emotion. The promotion of electronic types of various and well-functioning prints has become one of the priorities. The current development of electronic and audio-visual media, computer technologies, globalization in the information space, of course, affect the new methods of development of texting communication, language development, the way media texts are created and grasped, symbol or emoticon could be the next trend.

\section{KEYWORDS}

Media text; semiotics, semiology, image, indicators, symbols, abbreviations, acronyms, emoticons, personality, emotion, social networking, concrete sign, rhetorical means.

\section{INTRODUCTION}

The Semiotic analysis of media text (an analysis of the language of signs and symbols in media texts) has been becoming actual more and more in the spanning globe. This 
analysis is closely linked to the iconographic analysis. Semiotics, also called semiology, the study of signs and sign-using behaviour. It was defined by one of its founders, the Swiss linguist Ferdinand de Saussure, as the study of "the life of signs within society." Saussure identifies the symbol with the signifier (Saussure, 1998). Saussure's symbol is always motivated and defined in relation to the interpreter: "the modern reader is motivated to give a symbolic interpretation due to the deficiencies, the omissions, the errors of the text transmission" (Todorov, 1983: 397). Although the word was used in this sense in the 17th century by the English philosopher John Locke, the idea of semiotics as an interdisciplinary mode for examining phenomena in different fields emerged only in the late 19th and early 2oth centuries with the independent work of Saussure and of the American philosopher Charles Sanders Peirce. Semiotic analysis of media texts for training purposes based on the semiotic theory of media, to study some issues of semiotic analysis in the work of such theorists as R. Barthes [Barthes, 1964], C. Metz [Metz, 1964], U. Eco [Eco, 1976] and others. Identification analysis is the recognition / identification of hidden messages in media texts, because media agencies often offer simplistic solutions for complex problems.

\section{MATERIALS AND METHODS}

Researcher and media educator A. Berger emphasizes that the sign from the perspective of semiotics, can be anything that symbolizes or represents something else [Berger, 2005, p.55]. Signs can be divided into image (displays some easily recognizable resemblance to real objects), indicators (situational displays the connection that you can define logical: for example, fire and smoke) and symbols (display conditional values that require special knowledge - for example, the symbolism of flags of different States [Berger, 2005, p.247]. Likewise, the symbol can be any object and any phenomenon. The symbol - a sign, an image embodying any idea; visible, audible rarer phenomenon, which people attach a special meaning that is not associated with the essence of this phenomenon. The meaning of the symbol hints at what is for his sensually perceived appearance.

Considering the symbol as a trope, Mihaela Mancaş gives it the following definition: "the name of an object, conventionally chosen to designate a whole class of objects, an abstract notion or a predominant feature that it can be related to" (Mancaş, 2005: 358). The symbol includes two major features: "it is a name which is always extracted from the semantic field of concrete objects" (Mancaş, 2005: 358) and the substitution of a term by the other has a motivated character. The symbol (gr. symbolon / lat. symbolum "conventional sign") is "the figure of speech by which an abstract idea is expressed with the help of the name of an object belonging to the physical or animal world, on the basis of an easily perceivable analogy" (Dragomirescu, 1995: 255).

For Gabriela Duda, the symbol is "the analogous relation between an aspect of the ideal world and an element of the visual material world" (Duda, 2000: 72). The basis of the relation which is established between the symbolized aspect and the symbolizing element is one of mediation, the literary symbol being built on an existing relationship of designation that can highlight both a denotative meaning and a connotative one. The symbol is seen as "a concrete sign which, by the disclosed representations or by the 
suggested similarities, it conventionally designates something different from what it is" (Bălu, lancu, 2006: 15). In Eugen Negrici's opinion, symbols are "mediating words"( Eugen Negrici, 1988), placed in the text to keep the reader close, in an attempt to determine him to keep looking for the idea.

When you're typing with your thumbs, you need to save your effort by communicating with as few letters as possible. Consequently, users created text message symbols as a sort of shorthand to make texting easier and faster. Most symbols make sense and have become a mainstay in texting language.

\section{RESULT AND DISCUSSION}

There are a few different ways the unique language of text messaging is created. Some text message symbols abbreviate words by leaving out vowels or replacing several letters with a single letter that has the same sound. Others are acronyms, replacing an entire sentence with the first letter of each word. There are many symbols, abbreviations and acronyms that express human feelings and illustrate different behavior cases, however they all have specific usage and meaning.

An abbreviation (from Latin brevire $\rightarrow$ brevis meaning "short") is a shortened form of a word or phrase used mainly in writing to represent the complete form. It usually has a full-stop at the end.

Examples: Lib. For Library / abbr. for abbreviation / approx. for approximate

An acronym (from Latin acro- meaning "beginning" + -onym meaning "word, name") is a pronounceable word formed mostly (but not always) from the initial letters of a descriptive name or title. Examples: DIY - Do it Yourself, ASAP = as soon as possible.

\section{List of Internet Acronyms}

$\begin{array}{ll}2 \mathrm{~F} 4 \mathrm{U} & \text { Too Fast For You } \\ \text { 4YEO } & \text { For Your Eyes Only } \\ \text { AAMOF } & \text { As a Matter of Fact } \\ \text { ACK } & \text { Acknowledgment } \\ \text { AFAIK } & \text { As far as I know } \\ \text { AFAIR } & \text { As far as I remember / recall }\end{array}$

Other wide-spread symbols are Emoticons. They are pictures or faces made from characters on a cell phone's keypad. You can choose to send emoticons to express your mood or add enough humor or personality to a message rather than typing out an entire message. The term emoticon comes from "emotion and icon" and refers to facial expressions represented by keyboard characters. For example, the emoticon :-)

Represents a happy face and :-(

$\because$

Represents a sad face.

By entering an emoticon into a message, you can help the receiver better understand the feeling you want to get across.

While most emoticons represent expressions, they have branched out to symbolize many other things, such as people, animals, objects, and actions. Some emoticons are meant to be read left-to-right, while others are displayed vertically. Below are examples of different types of emoticons: 


$$
\text { Hugs }
$$

$(((H)))$

$$
\text { Kiss }
$$

Laughing

$:-\mathrm{D}$

Very happy

$:-\mathrm{D}$

Confused

0.0

:-) Smiling with curls

(-: Smiling

:' ) Happy and crying

:@ Shouting

:'-( Crying

>:-@! Angry and swearing

$>:-($ Very angry

$:-($ Sad

:-() Shocked

:-|| Angry

:- ) Having a cold

$:-<>$ Surprised

:-c Unhappy

\section{CONCLUSION}

With these symbols, not only will you save time, but you will be able to send longer texts that contain more personality and emotion. You may also use these symbols when sending messages on popular social networking sites. If you cannot find a symbol or emoticon to fit your needs, create one by yourself and send it to your friends. Who knows? Your created symbol or emoticon could be the next trend. The first approach of this article was to bring into relief the main theories about the symbol, a figure with high frequency in the poetical text, but often left aside, as its various typology and the difficulty in formalizing the logical and semantic interactions between the terms of the symbol. Therefore, the symbol is seen as a trope, as a concrete sign, as a rhetorical means, as an instrument of an action of psychological identification or of mystical revelation, as a metalogism which modifies the relation with the referent and alters the context, as a nonsign, as an unmotivated sign, as a cipher of absolute realities, as a figure in relation to the metaphor, the metonymy and the allegory.

\section{REFERENCES}

1. Mancaş, Mihaela, (2005), Modern Romanian Artistic Language. Sketch of Development, University of Bucharest Publishing House, Bucharest;

2. Mancaş, Mihaela, (2005), Modern Romanian Artistic Language. Sketch of Development, University of Bucharest Publishing House, Bucharest;

3. Mancaş, Mihaela, (2005), Modern Romanian Artistic Language. Sketch of Development, University of Bucharest Publishing House, Bucharest;

4. Dragomirescu, Gh., N., (1995), Dictionary of the Figures of Speech, Scientific Publishing House, Bucharest;

5. Duda, Gabriela, (2000), The Analysis of the Literary Text, Humanitas Educational Publishing House, Bucharest;

6. Negrici, Eugen, (1988), Systematics of the Poetry, Romanian Book Publishing House, Bucharest;

7. Duda, Gabriela, (2002) The Metaphor in the Romanian Symbolistic Poetry, Eminescu Publishing House, Bucharest;

8. Todorov, T., (1974) Researches on Linguistic Symbolism, "Poetics";

9. Todorov, Tzvetan, (1983), Theories of the Symbol, Univers Publishing House. 